\title{
Use Of Global Positioning System (Grs) For Basic Survey On Students
}

\section{Penggunaan Global Positioning System (Gps) Untuk Dasar Survey Pada Mahasiswa}

\author{
Petrisly Perkasa ${ }^{1)}$ \\ 1), Program Studi Pendidikan Teknik Bangunan, FKIP, UPR \\ Kampus Unpar Tunjung Nyaho, Jl. H. Timang, 73111A \\ e-mail: petris.perkasa@ptb.upr.ac.id
}

\begin{abstract}
As been coming ages, modern technology integrates into every life aspect including in field survey. Nowadays, one of the modern technology namely Global Positioning System (GPS). The GPS system was first developed by the US Department of Defense used for both military and civilian purposes. This system is designed to provide threedimensional position, speed, and information about world which is not affected by time and weather. Presently, GPS has been widely used by people all over the world who is need information about position, speed or time. To determine the coordinates of points on earth, the receiver requires at least 4 satellites to capture the signal correctly with the coordinates obtained referring to the global datum such World Geodetic System 1984 (WGS'84). GPS is divided into 3 types: Type of navigation or handheld, generally used in battle field or navigation purposes. Some vehicles have been equipped with GPS for navigation aids by adding a map to guide the rider thus rider know which pathway should be chosen to arrived at the destination. GPS mapping is a GPS tool used to calculate an area or create an important route in transit. Type Mapping has an accuracy level between 1-3 meters and mapping types require a base station serving to receive satellite signals and transmit them to a GPS receiver. Geodetic type is the most meticulous and most sophisticated type than navigation or mapping because it has a level of accuracy below 1 meter. The price of geodetic type is most expensive.
\end{abstract}

Keywords: Survey, GPS, Coordinates

\begin{abstract}
ABSTRAK
Seiring bertambahnya zaman, teknologi modern masuk ke dalam setiap aspek kehidupan.Termasuk di bidang survey yang semakin mudah dan modern sekarang hadir dengan nama Global Positioning System (GPS). Sistem GPS pertama kali dikembangkan oleh Departemen Pertahanan AS yang digunakan untuk keperluan militer dan sipil. Sistem ini dirancang untuk memberikan posisi dan kecepatan tiga dimensi dan informasi kepada dunia terlepas dari waktu dan cuaca. Saat ini GPS telah banyak digunakan oleh orang-orang di seluruh dunia yang membutuhkan informasi tentang posisi, kecepatan atau ketepatan waktu. Untuk GPS menentukan koordinat titik di bumi, receiver memerlukan setidaknya 4 satelit untuk menangkap sinyal dengan benar dengan koordinat yang diperoleh yang mengacu pada datum global yaitu World Geodetic System 1984 atau disingkat WGS'84 dan berdasarkan fungsinya GPS terbagi menjadi 3 jenis: Jenis navigasi atau handheld, umumnya digunakan di medan militer atau untuk keperluan navigasi. Beberapa kendaraan telah dilengkapi GPS untuk alat bantu navigasi, dengan menambahkan peta, bisa digunakan untuk membimbing pengendara, sehingga pengendara bisa mengetahui jalur mana yang harus dipilih untuk mencapai tujuan yang diinginkan. Pemetaan GPS adalah alat GPS yang digunakan untuk menghitung area atau membuat rute penting dalam perjalanan. Jenis Pemetaan memiliki tingkat akurasi antara 1 - 3 meter dan tipe pemetaan biasanya memerlukan stasiun pangkalan yang berfungsi untuk menerima sinyal satelit dan mengirimkannya ke penerima GPS. Jenis geodetik adalah tipe yang paling teliti dan paling canggih dibandingkan tipe navigasi atau tipe pemetaan karena memiliki tingkat akurasi di bawah 1 meter, dan harganya juga yang paling mahal.
\end{abstract}

Kata Kunci: Survey, GPS, Koordinat.

\section{PENDAHULUAN}

GPS (Global Positioning System) adalah sistem satelit navigasi dan penentuan posisi yang dimiliki dan dikelola oleh Amerika Serikat. Sistem ini didesain untuk memberikan posisi dan kecepatan tiga dimensi serta informasi mengenai waktu, secara berkesinambungan di seluruh dunia tanpa bergantung waktu dan cuaca bagi banyak orang. Saat ini GPS sudah banyak digunakan orang di seluruh dunia dalam berbagai bidang aplikasi yang menuntut informasi tentang posisi, kecepatan ataupun waktu yang teliti.Kemampuan GPS antara lain dapat memberikan informasi tentang posisi, kecepatan, dan waktu secara cepat, akurat, murah, dimana saja di bumi ini tanpa tergantung cuaca.

Satelit GPS dapat dianalogikan sebagai stasiun radio angkasa, yang diperlengkapi dengan antena-antena untuk mengirim dan menerima sinyal-sinyal gelombang. Sinyalsinyal ini selanjutnya diterima oleh receiver GPS didekat permukaan bumi, dan digunakan untuk menentukan informasi posisi, kecepatan, maupun waktu. Segmen 
pengguna terdiri dari para pengguna satelit GPS di manapun berada. Dalam hal ini alat penerima sinyal GPS (GPS receiver) diperlukan untuk menerima dan memproses sinyal-sinyal dari satelit GPS untuk digunakan dalam penentuan posisi, kecepatan dan waktu. Komponen utama dari suatu receiver GPS secara umum adalah antena untuk mengidentifikasi sinyal,memproses sinyal dan memproses data dan menampilkan data tersebut.

Ada 3 macam tipe alat GPS, dengan masing-masing memberikan tingkat ketelitian (posisi) yang berbedabeda. Tipe alat GPS pertama adalah tipe Navigasi (Handheld, Handy GPS). Tipe nagivasi harganya cukup murah, sekitar 1 sampai dengan 4 juta rupiah, namun ketelitian posisi yang diberikan saat ini baru dapat mencapai 3 sampai 6 meter. Tipe alat yang kedua adalah tipe geodetik single frekuensi (tipe pemetaan), yang biasa digunakan dalam survey dan pemetaan yang membutuhkan ketelitian posisi sekitar sentimeter sampai dengan beberapa desimeter. Tipe terakhir adalah tipe Geodetik dual frekuensi yang dapat memberikan ketelitian posisi hingga mencapai milimeter. Tipe ini biasa digunakan untuk aplikasi precise positioning seperti pembangunan jaring titik kontrol, survey deformasi, dan geodinamika. Harga receiver tipe geodetik cukup mahal, mencapai ratusan juta rupiah untuk 1 unitnya sedangkan pada penulisan jurnal ini menggunakan tipe Navigasi.

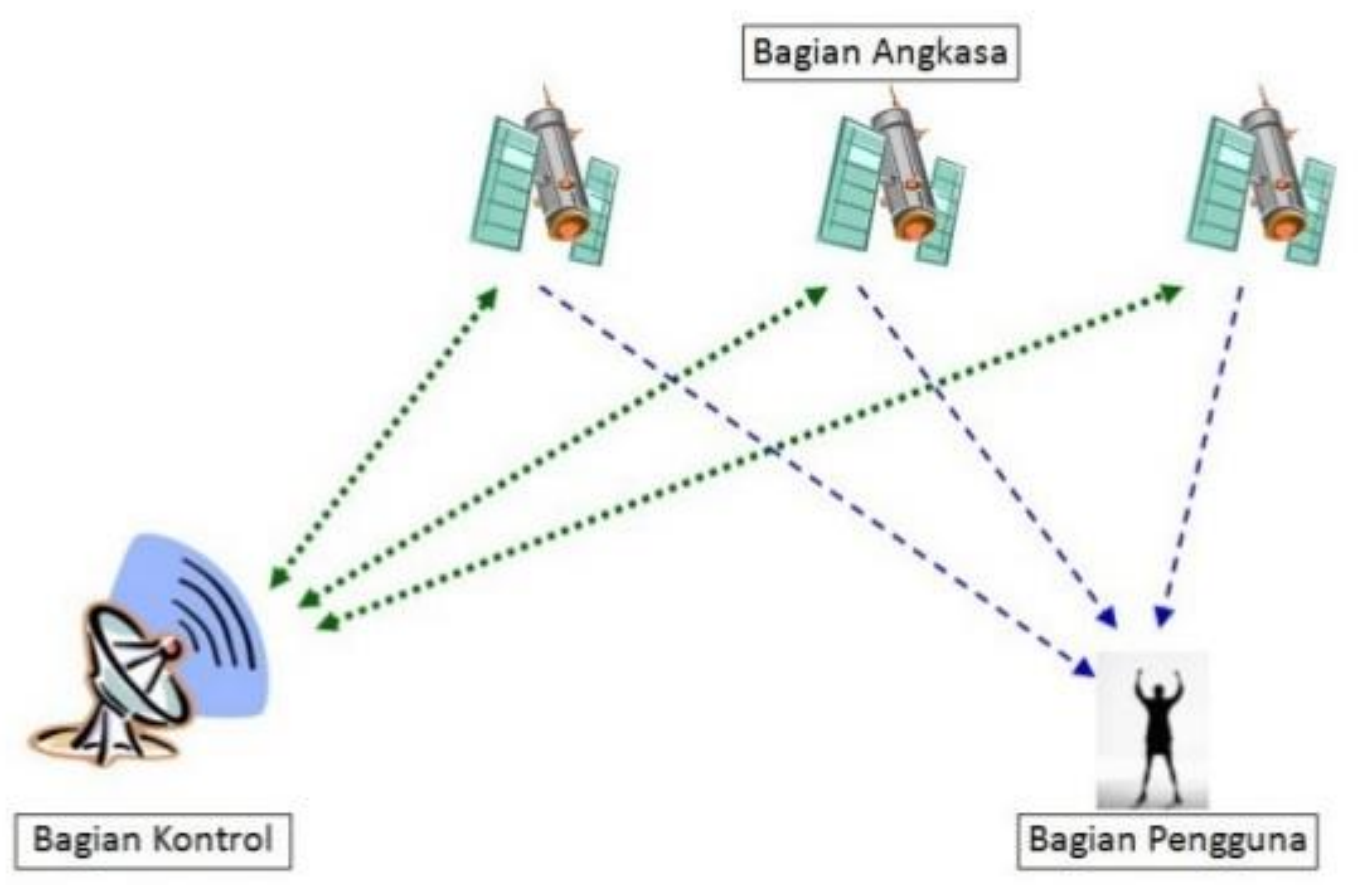

Gambar 1.Cara Kerja GPS (Global Positioning System) Sumber: https://camargus.com/magazine/231

\section{TUJUAN}

Tujuan dari penelitian ini adalah: (1) Untuk mengetahui alat ukur Global Positioning System (GPS) untuk melakukan survey dasar. (2) Mengetahui fungsi setiap bagian pada alat ukur Global Positioning System (GPS). (3) Mengetahui cara penggunaan alat ukur Global Positioning System (GPS).

\section{HASIL YANG DIHARAPKAN}

Hasil yang diharapkan dari penelitian ini adalah: (1) Mahasiswa mampu mengaplikasikan teori yang didapat dan menggunakan alat Global Positioning System (GPS) tipe Navigasi untuk survey tingkat dasar. (2) Bagi praktisi sebagai bahan masukan pentingnya data yang memiliki informasi spasial. (3) Bagi Akademisi untuk memperluas dan menambah wawasan tentang penggunaan Global Positioning System (GPS) tipe Navigasi. 


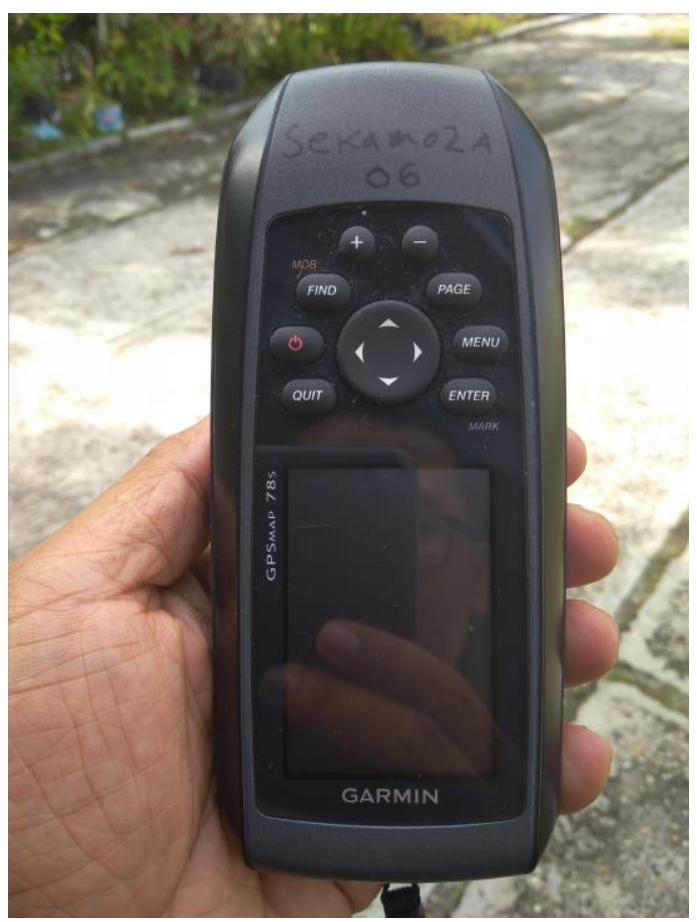

Gambar 2. GPS (Global Positioning System) Tipe Navigasi yang digunakan Sumber: Dokumentasi Pribadi

\section{Dasar Teori Global Positioning System (GPS)}

Sistem GPS, yang mempunyai tiga segmen yaitu : satelit, pengontrol, dan penerima pengguna. Satelit GPS yang mengorbit bumi, dengan orbit dan kedudukan yang tetap (koordinatnya pasti), seluruhnya berjumlah 24 buah dimana 21 buah aktip bekerja dan 3 buah sisanya adalah cadangan.

1. Satelit bertugas untuk menerima dan menyimpan data yang ditransmisikan oleh stasiun-stasiun pengontrol, menyimpan dan menjaga informasi waktu berketelitian tinggi (ditentukan dengan jam atomic di satelit), dan memancarkan sinyal dan informasi secara kontinyu ke pesawat penerima (receiver) dari pengguna. Terdiri dari satelit-satelit yang mengorbit mengelilingi bumi, jumlah satelit GPS adalah 24 buah. Setelit GPS mengorbit mengelilingi bumi dalam bidang orbit dengan tinggi rata-rata setiap satelit $\pm 20.200 \mathrm{Km}$ dari permukaan bumi. di mana-mana di muka bumi selalu ada cukup satelit untuk penentuan posisi yang bagus.

2. Pengontrol bertugas untuk mengendalikan dan mengontrol satelit dari bumi baik untuk mengecek kesehatan satelit, penentuan dan prediksi orbit dan waktu, sinkronisasi waktu antar satelit, dan mengirim data ke satelit. Stasiun kontrol ini tersebar diseluruh dunia, yaitu dipulau Ascension. Diego Garcia. Kwajalein, Hawai dan Colorado Springs.

3. Penerima bertugas menerima data dari satelit dan meprosesnya untuk menentukan posisi (posisi tiga dimensi yaitu koordinat di bumi plus ketinggian), arah, jarak dan waktu yang diperlukan oleh pengguna. Ada dua macam tipe penerima yaitu tipe Navigasi dan tipe Geodetic. Yang termasuk receiver tipe Navigasi antara lain : Trimble Ensign, Trimble Pathfinder, Garmin, Sony dan lain sebagainya. Sedangkan tipe Geodetic antara lain : Topcon, Leica, Astech, Trimble seri 4000 dan lain-lain.

Untuk menentukan koordinat suatu titik di bumi, receiver setidaknya membutuhkan 4 satelit yang dapat ditangkap sinyalnya dengan baik. Secara default posisi atau koordinat yang diperoleh bereferensi ke global datum yaitu World Geodetic System 1984 atau disingkat WGS'84.

Secara garis besar penentuan posisi dengan GPS ini dibagi menjadi dua metode yaitu metode absolut dan metode relatif.

1. Metode absolut atau juga dikenal sebagai point positioning, menentukan posisi hanya berdasarkan pada 1 pesawat penerima (receiver) saja. Ketelitian posisi dalam beberapa meter dan umumnya hanya diperuntukkan bagi keperluan Navigasi. 
Karakteristik penentuan posisi dengan cara absolut ini adalah sebagai berikut:

- Satelit-satelit mengirim sinyal secara terus menerus.

- Receiver GPS menerima sinyal tersebut dan menghitung jarak ke satelit tersebut receiver GPS menerima sinyal dari minimal 4 satelit dan mengkalkulasi posisi receiver GPS

2. Metode relatif atau sering disebut differential positioning, menentukan posisi dengan menggunakan lebih dari sebuah receiver. Satu GPS dipasang pada lokasi tertentu dimuka bumi dan secara terus menerus menerima sinyal dari satelit dalam jangka waktu tertentu dijadikan sebagai referensi bagi yang lainnya. Metode ini menghasilkan posisi ketelitian yang tinggi dan diaplikasikan untuk keperluan survei geodesi ataupun pemetaan yang memerlukan ketelitian tinggi. pengukuran dilakukan secara bersamaan pada dua titik dalam selang waktu tertentu:

- Memerlukan minimal 2 receiver, satu ditempatkan pada titik yang telah diketahui koordinatnya.

- Posisi titik ditentukan relatif terhadap titik yang diketahui.

- Konsep dasar adalah differencing process dapat mengeliminir atau mereduksi pengaruh dari beberapa kesalahan dan bias.

- Ketelitian posisi yang diperoleh bervariasi dari tingkat $\mathrm{mm}$ sampai dengan $\mathrm{dm}$.

- Aplikasi utama: survei pemetaan, survei penegasan batas, survei geodesi dan navigasi dengan ketelitian tinggi.

\section{Berdasarkan fungsinya receiver GPS dibagi menjadi 3 tipe yaitu:}

- Tipe Navigasi (Handheld, Handy GPS)

Tipe navigasi atau handheld, pada umumnya digunakan pada bidang militer atau untuk keperluan navigasi. Beberapa kendaraan telah dilengkapi dengan GPS untuk alat bantu navigasi, dengan menambahkan peta, maka bisa digunakan untuk memandu pengendara, sehingga pengendara bisa mengetahui jalur mana yang sebaiknya dipilih untuk mencapai tujuan yang diinginkan.Pada GPS tipe navigasi seperti ini memiliki kekurangan seperti tingkat ketelitian yang sangat rendah. Yaitu hanya mencapai 3-6 meter, yang artinya apabila alat tersebut menunjukkan suatu titik, maka titik tersebut berada sekitar 3 sampai 6 meter disekitarnya. Jadi belum presisi, namun karena alat ini biasanya hanya digunakan untuk keperluan militer dan penunjuk arah, maka tidak masalah. Karena selain itu GPS ini memiliki kelebihan yaitu ringan, mudah dibawa-bawa, mudah digunakan karena tidak memerlukan pemahaman tingkat tinggi, dan murah. Bagi para pemula, dan pengguna dengan tujuan navigasi penggunaan GPS tipe navigasi sudah cukup.

- Tipe mapping

GPS mapping adalah alat GPS yang digunakan menghitung luas atau membuat rute penting dalam perjalanan. Tipe Mapping (Pemetaan) Mempunyai tingkat akurasi antara 1 - 3 meter dan tipe mapping biasanya membutuhkan base station yang berfungsi untuk menerima sinyal satelit dan mengirimnya ke receiver GPS. Tipe ini biasa digunakan untuk survey dan Pemetaan dan setelah didownload ke pemetaan dan setelah didownload ke komputer dapat dilakukan koreksi secara diferensial.

- Tipe Geodetik

Tipe Geodetik merupakan tipe yang paling teliti dan paling canggih dibanding dengan tipe navigasi ataupun tipe mapping karena mempunyai tingkat akurasi dibawah 1 meter,dan harganya pun paling mahal 


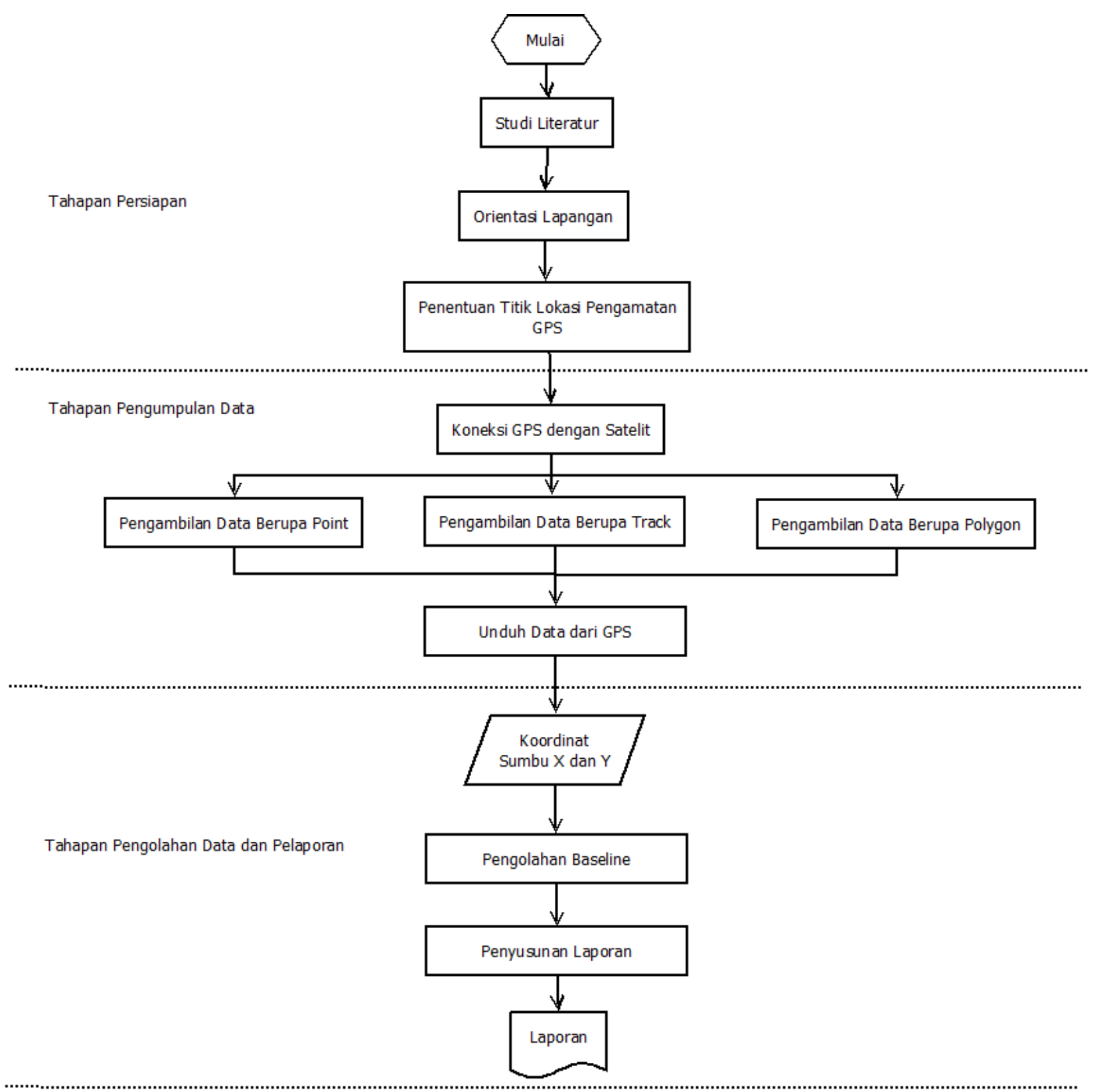

Gambar 3. Diagram Alir Penelitian

\section{CARA KERJA GPS}

Setiap daerah di atas permukaan bumi ini minimal terjangkau oleh 3 sampai dengan 4 satelit. Pada prakteknya, setiap GPS terbaru bisa menerima sampai dengan 12 channel satelit sekaligus. Kondisi langit yang cerah dan bebas dari halangan membuat GPS dapat dengan mudah menangkap sinyal yang dikirimkan oleh satelit. Semakin banyak satelit yang diterima oleh GPS, maka akurasi yang diberikan juga akan semakin tinggi. Cara kerja GPS ada 5 langkah yaitu:
- Memakai perhitungan "triangulation" dari satelit.

- Untuk perhitungan "triangulation" GPS mengukur jarak menggunakan travel time sinyal radio.

- Untuk mengukur travel time, GPS memerlukan memerlukan akurasi waktu yang tinggi.

- Untuk perhitungan jarak, kita harus tahu dengan pasti posisi satelit dan ketingian pada orbitnya. 
- Terakhir harus koreksi sinyal waktu perjalanan di atmosfer sampai diterima receiver.

Satelit GPS berputar mengelilingi bumi selama 12 jam di dalam orbit yang akurat dia dan mengirimkan sinyal informasi ke bumi. GPS mengambl informasi itu dan dengan menggunakan perhitungan "triangulation" menghitung lokasi user dengan tepat. GPS reciever membandingkan waktu sinyal di kirim dengan waktu sinyal tersebut di terima. Dari informasi itu didapat diketahui berapa jarak satelit. Dengan perhitungan jarak GPS reciever dapat melakukan perhitungan dan menentukan posisi user dan menampilkan dalam peta elektronik. Sebuah GPS reciever harus mengunci sinyal minimal tiga satelit untuk menghitung posisi 2D (latitude dan longitude) dan track pergerakan. Jika GPS receiver dapat menerima empat atau lebih satelit, maka dapat menghitung posisi 3D (latitude, longitude dan altitude). Jika sudah dapat menentukan posisi user, selanjutnya GPS dapat menghitung informasi lain, seperti kecepatan, arah yang dituju, jalur, tujuan perjalanan, jarak tujuan, matahari terbit dan matahari terbenam dan masih banyak lagi.

Ketinggian itu menimbulkan keuntungan dalam mendukung proses kerja GPS, bagi kita karena semakin tinggi maka semakin bersih atmosfer, sehingga gangguan semakin sedikit dan orbit yang cocok dan perhitungan matematika yang cocok. Satelit harus tetap pada posisi yang tepat sehingga stasiun di bumi harus terus memonitor setiap pergerakan satelit, dengan bantuan radar yang selalu di cek tentang altitude, posisi dan kecepatannya.

\section{Sistem koordinat pada GPS}

Pengenalan tentang sistem koordinat sangat penting agar dapat menggunakan GPS secara optimum. Setidaknya ada dua klasifikasi tentang sistem koordinat yang dipakai oleh GPS maupun dalam pemetaan yaitu : sistem koordinat global yang biasa disebut sebagai koordinat geografi dan sistem koordinat di dalam bidang proyeksi. Koordinat geografi diukur dalam lintang dan bujur dalam besaran derajad desimal, derajad menit desimal, atau derajad menit detik Lintang diukur terhadap equator sebagai titik nol $\left(0^{\circ}\right.$ sampai $90^{\circ}$ positif kearah utara dan $0^{\circ}$ sampai $90^{\circ}$ negatif kearah selatan). Bujur diukur berdasarkan titik nol di Greenwich $0^{\circ}$ sampain $180^{\circ}$ kearah timur dan $0^{\circ}$ sampai $180^{\circ}$ kearah barat. Koordinat di dalam bidang proyeksi merupakan koordinat yang dipakai pada sistem proyeksi tertentu. Umumnya berkait erat dengan sistem proyeksinya, walaupun adakalanya (karena itu memungkinkan) digunakan koordinat geografi dalam bidang proyeksi. Beberapa sistem proyeksi yang lazim digunakan di Indonesia di antaranya adalah : proyeksi Merkator, Transverse Merkator, Universal Transverse Merkator (UTM. Masing-masing sistem tersebut ada kelebihan dan kekurangan dan pemilihan proyeksi umumnya didasarkan pada tujuan peta yang akan dibuat. Dari beberapa sistem proyeksi tersebut, proyeksi Transverse Merkator banyak dipakai di Indonesia.

Beberapa istilah penting yang penting untuk diketahui yang berhubungan dengan GPS :

- Waypoint

Istilah yang digunakan oleh GPS untuk suatu lokasi yang telah ditandai. Waypoint terdiri dari koordinat lintang (latitude) dan bujur (longitude). Sebuah waypoint biasa digambarkan dalam bentuk titik dan simbol sesuai dengan jenis lokasi.

- Mark

Menandai suatu posisi tertentu pada GPS. Jika menandai lokasi menjadi waypoint,maka dikatakan telah melakukan marking.

- Route

Kumpulan waypoint yang ingin seseorang tempuh secara berurutan dan dimasukkan ke dalam GPS.

- Track

Arah perjalanan yang sedang ditempuh dengan menggunakan GPS. Biasanya digambarkan berupa garis pada display GPS.

- Elevation

Istilah pada GPS untuk menentukan ketinggian. Ada dua jenis pengukur ketinggian pada GPS, yaitu menggunakan alat klasik 'Barometer' atau menggunakan perhitungan satelit. Pengukuran ketinggian menggunakan barometer jauh lebih akurat di udara bebas, namun tidak bisa bekerja dalam pesawat atau ruang vakum lainnya.Ini disebabkan oleh perbedaan tekanan udara dalam ruang vakum dengan tekanan udara di luar. Pengukuran ketinggian menggunakan satelit akan lebih akurat pada tempat seperti itu.

- Bearing

Arah/posisi yang ingin dituju. Contohnya, A ingin menuju ke suatu lokasi di posisi B yang letaknya di Utara, maka bearing A dikatakan telah diset ke Utara.

- Heading

Arah aktual yang sedang dijalankan. Contohnya, saat menuju ke posisi B tadi, A menemui halangan sehingga harus memutar ke selatan terlebih dahulu, maka heading A pada saat itu adalah selatan.

\section{BAHAN DAN ALAT}

Bahan yang digunakan lembar kerja untuk rekapitulasi, Landasan papan untuk menulis, Ballpoint, Baterai untuk GPS dan peralatan yang digunakan adalah seperangkat Laptop dengan hard disk $500 \mathrm{~GB}$, processor Intel Core i5 $2400 \mathrm{MHz}$, RAM 4,00 GB, monitor 13 Inci, dan Perangkat keras GPS Map (Global Positioning System) Tipe Navigasi $78 \mathrm{~S}$. 


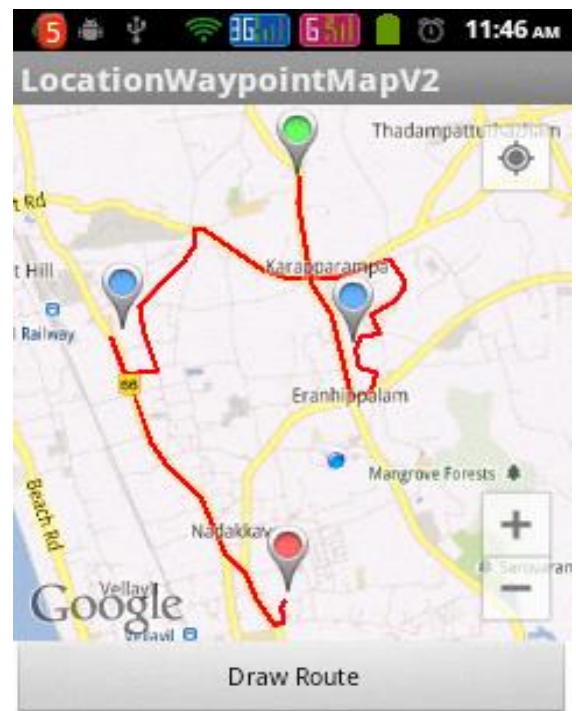

Gambar 4.Penggunaan Waypoint untuk memberi nama suatu objek

Sumber : http://wptrafficanalyzer.in/blog/route-between-two-locations-with-waypoints-in-google-map-android-api-v2/

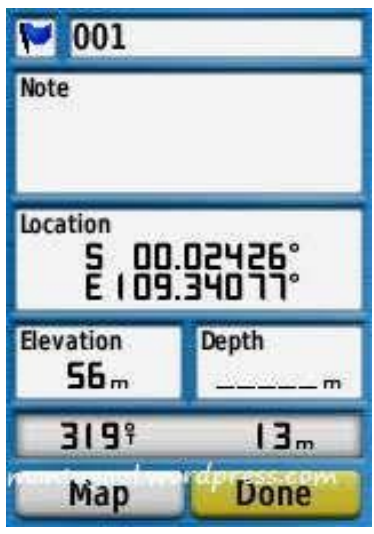

Gambar 5.Fitur Mark untuk menandai suatu objek atau koordinat Sumber : https://mantugaul.wordpress.com/2010/07/27/review-gpsmap-garmin-78s-generasi-penerus-76csx/

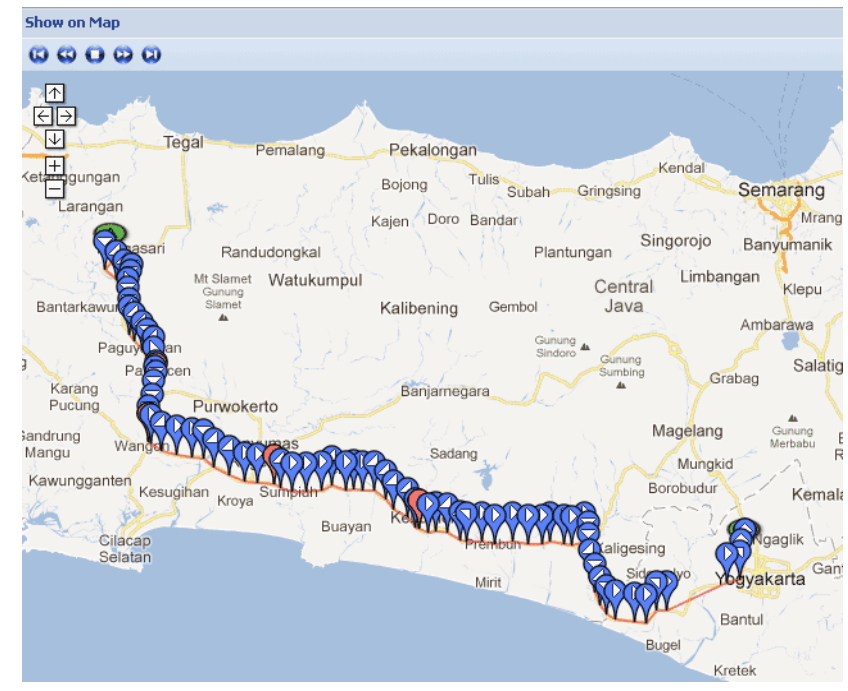

Gambar 6.Kumpulan Waypoint yang membentuk Route 
Sumber : http://www.solusitek.com/?p=3161

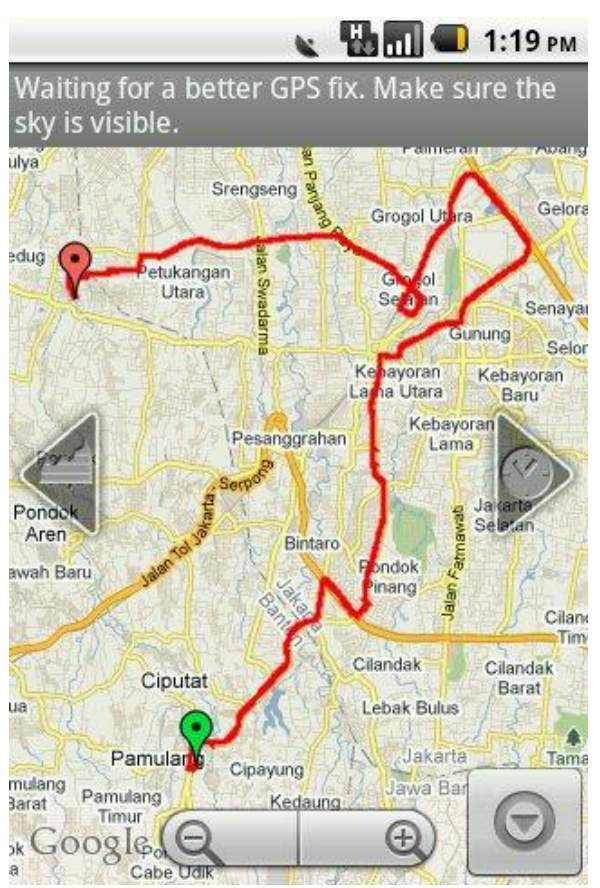

Gambar 7.Track jalur perjalanan

Sumber : https://paoir.wordpress.com/2011/07/07/my-tracks/

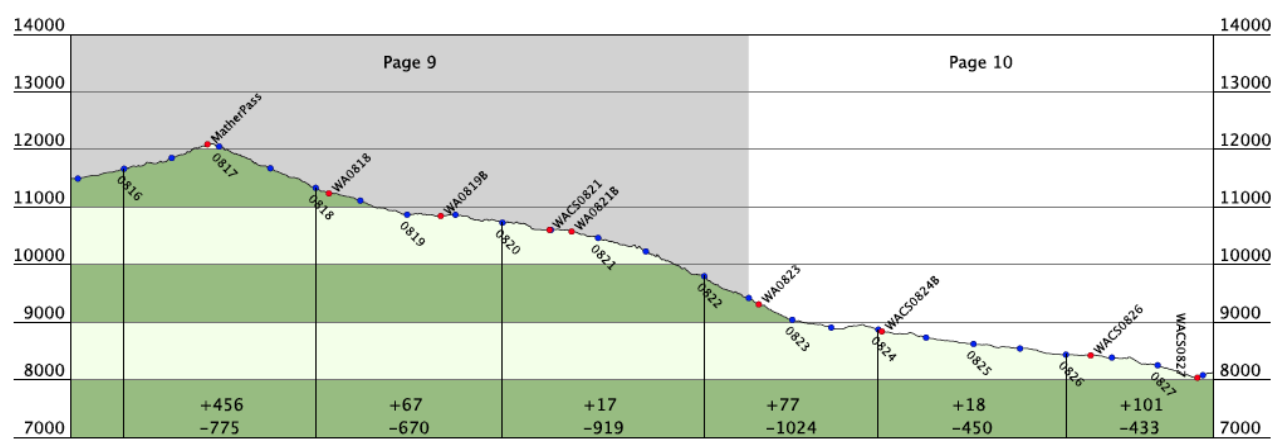

Gambar 8. Elevation berdasarkan jalur Track yang didapat Sumber : https://www.pctmap.net/2014/03/elevation-gain-on-the-pacific-crest-trail/

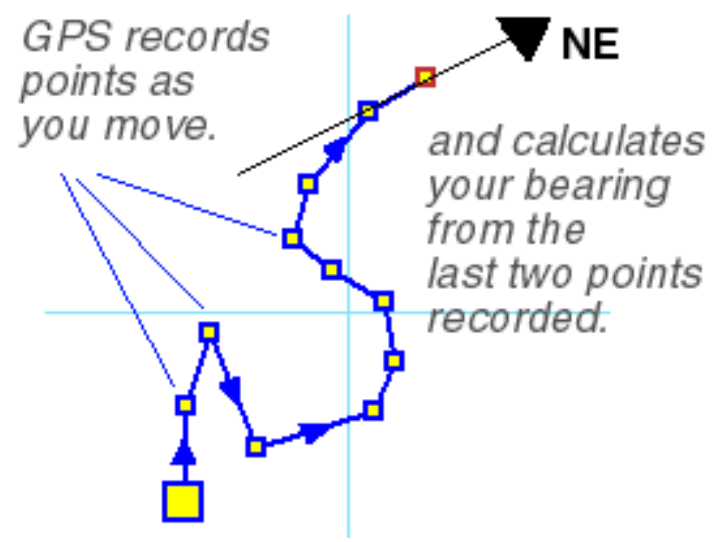

Gambar 9. Fitur Bearing diaktifkan untuk menuju arah yang dituju Sumber : http://www.tracklogs.co.uk/cgi-bin/publ/user.cgi?obj=support\&mod=kbase\&view=15885925 


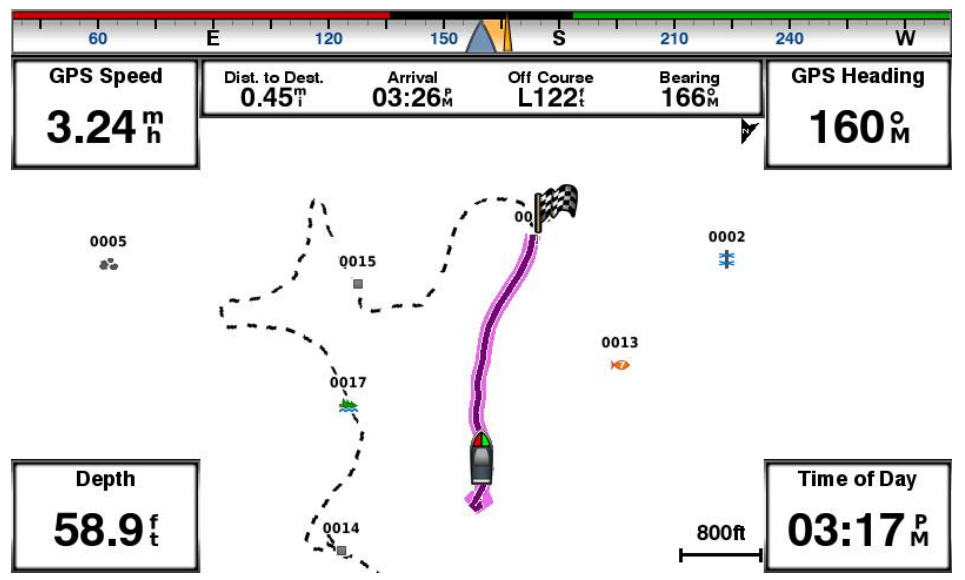

Gambar 10. Fitur Heading diaktifkan ketika objek yang dituju mengalami halangan akan ada arah alternatif Sumber : https://www.chsmith.com.au/Products/Garmin-Striker-7sv-CHIRP-Fishfinder.html

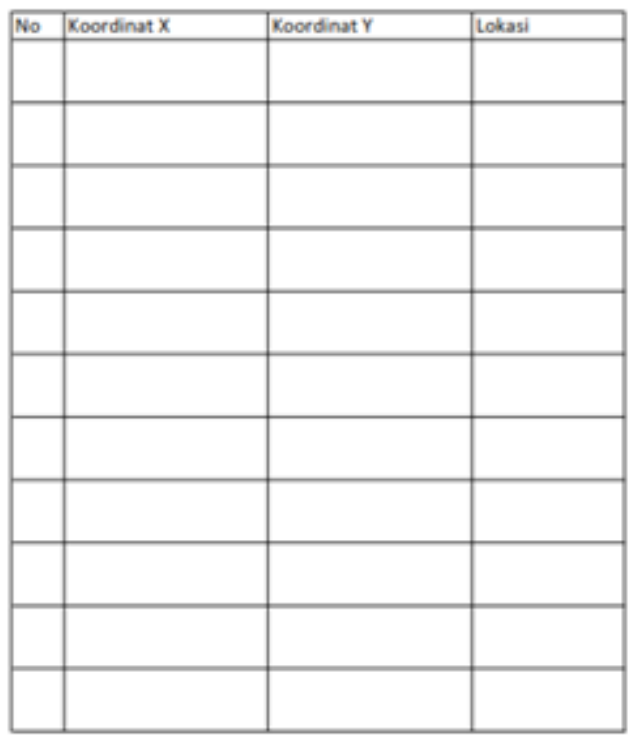

Palangka Raya

Surveyor,

Gambar 11. Lembar kerja untuk rekapitulasi data koordinat

\section{HASIL PRAKTIK DAN PEMBAHASAN}

1. Cara memulai.

- Pasang baterai.

- Aktifkan perangkat dengan menekan tombol (Light) yang berwarna merah.

- Mencari satelit lanjut pilih menu satelit di layar utama lanjut cari tempat yang terbuka agar cepat dan mudah menangkap sinyal. Selanjutnya, diamkan untuk beberapa saat untuk mencapai akurasi maksimum satelit.

2. Pengaturan GPS Garmin $78 \mathrm{~S}$.

a. Pilihlah (Setup) atau pengaturan di layar utama. b. Selanjutnya akan muncul menu lainnya dari pengaturan.

- Sistem lanjut GPS (Normal) lanjut Bahasa (Indonesia) lanjut tipe baterai (Lithium/Alkaline/NiMH) lanjut Interface (Garmin Serial).

- Tampilan lanjut waktu kecerahan layar disesuaikan dengan kebutuhan lanjut Battery save (on/off) lanjut warna disesuaikan dengan kebutuhan.

- Jejak lanjut log jejak (do not record/tidak merekam) lanjut metode rekam (otomatis) 
lanjut Interval (normal) lanjut simpan otomatis/auto archive (ketika penuh/when full) lanjut colors disesuaikan dengan kebutuhan.

- Satuan lanjut Jarak/kecepatan (Metrix) lanjut ketinggian (Meter, $\mathrm{m} / \mathrm{s}$ ) lanjut kedalaman (Meter) lanjut Suhu (Celcius) Lanjut Tekanan (Milimeter $\mathrm{Hg}$ )

- Waktu lanjut format waktu (24 jam) lanjut zona waktu (Bangkok,Hanoi dan Jakarta).

- Format posisi lanjut format posisi (UTM) lanjut Datum peta (WGS 83)

- Kalibrasi GPS adalah dengan melakukan putaran 2 kali secara pelan-pelan ke arah kanan. Dan GPS akan mengkalkulasi sinyal dari satelit stasioner di atasnya, untuk menentukan arah kompas dengan benar.

3. Penggunaan GPS Garmin 78S.

- Waypoint Marking adalah memperoleh koordinat dari suatu titik lokasi yang di survey. Dengan cara menekan tombol Enter dilanjutkan dengan tombol OK dan dilanjutkan dengan tombol Save.

- Tracking dalam peristilahan GPS adalah melakukan akuisisi data koordinat secara otomatis berdasarkan jalur yang kita lalui dan data tersebut disimpan dalam kartu memori
GPS secara otomatis pula. Untuk memulai tracking tekan tombol menu dua kali, maka akan muncul Menu Utama, pilih track, tekan Enter.

Untuk menyimpan hasil tracking dalam sebuah nama, tekan enter setelah kursor berada pada button Save. Anda bisa mengubah nama atau membiarkan nama default. Pada saat menyimpan ini anda akan diberi pilihan menyimpan seluruh track, atau menyimpan track yang baru saja anda lakukan. Untuk menampilkan dalam peta GPS klik pada salah satu dari daftar track yang ada. Pilih Map/maka peta dengan tracking yang anda lakukan akan muncul.

Route / Rute dalam peristilahan GPS adalah melakukan akuisisi data koordinat ( harus berupa titik ) secara otomatis berdasarkan jalur yang kita lalui dan data tersebut disimpan dalam kartu memori GPS secara otomatis pula. Disinilah letak perbedaan antara Track dan Route. Kalau dalam Track tidak dipersyaratkan menentukan titik yang akan diambil, sedangkan dalam Route diharuskan mencari / menentukan titik terlebih dahulu (karena Route digunakan untuk membuat Polygon)

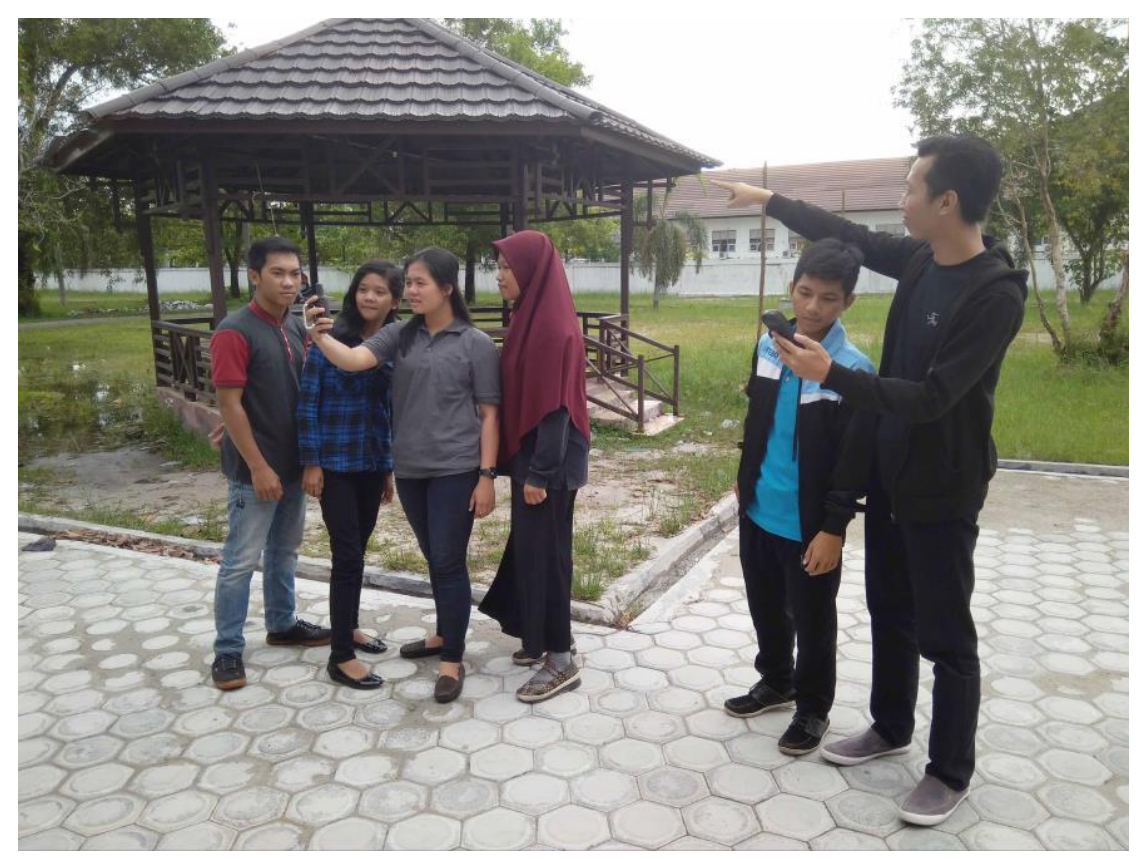

Gambar 12. Penggunaan GPS genggam untuk pengenalan survey dasar untuk mahasiswa PTB 

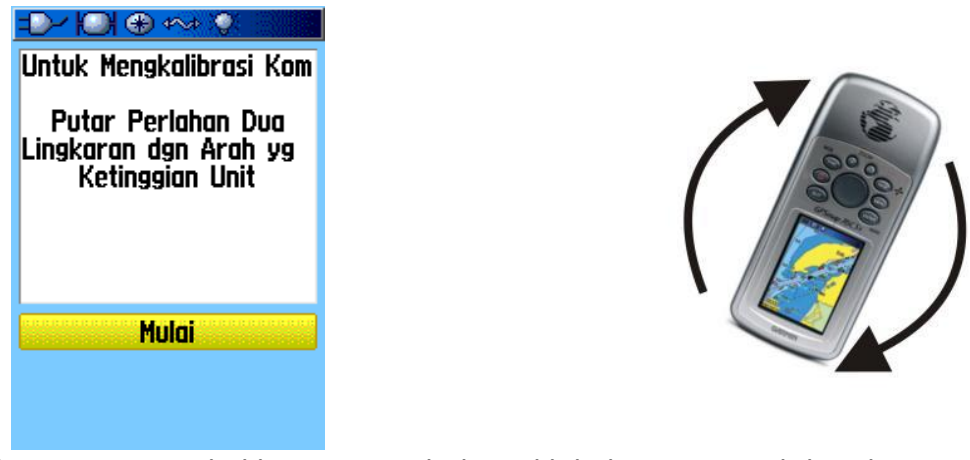

Gambar 13. Proses kalibrasi GPS sebelum dilakukan pengambilan data Sumber : http://pusdiklathut.org/baktirimbawan/modul_gps/BAHAN\%20AJAR\%20PENGGUNAAN\%20GPS.pdf

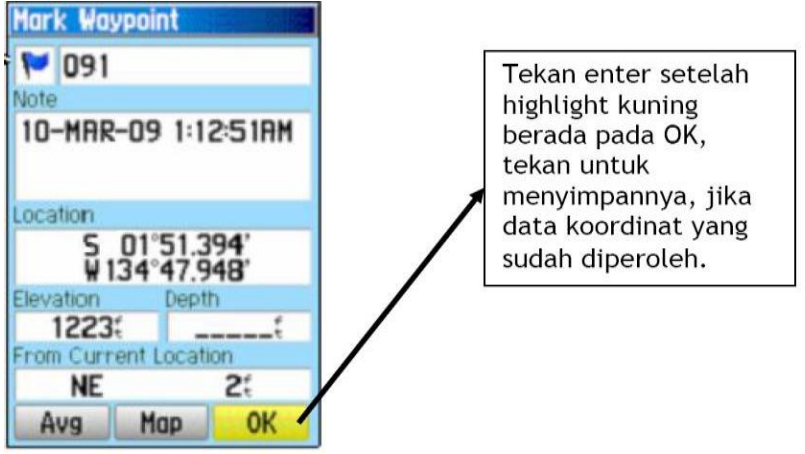

Gambar 14. Proses penandaan Waypoint pada GPS

Sumber : http://pusdiklathut.org/baktirimbawan/modul_gps/BAHAN\%20AJAR\%20PENGGUNAAN\%20GPS.pdf
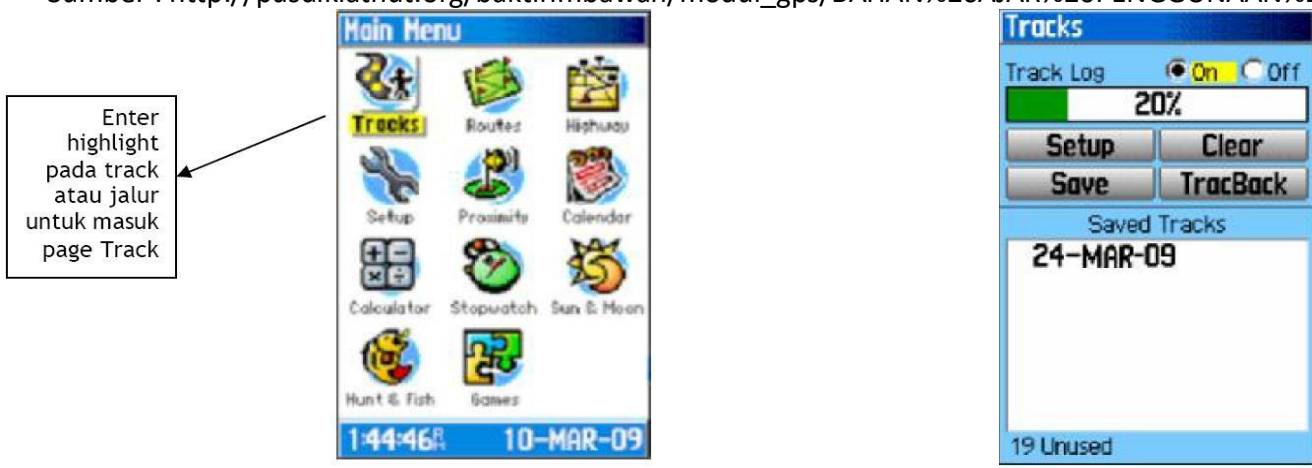

Gambar 15. Proses pengambilan data Track pada GPS

Sumber : http://pusdiklathut.org/baktirimbawan/modul gps/BAHAN\%20AJAR\%2OPENGGUNAAN\%20GPS.pdf
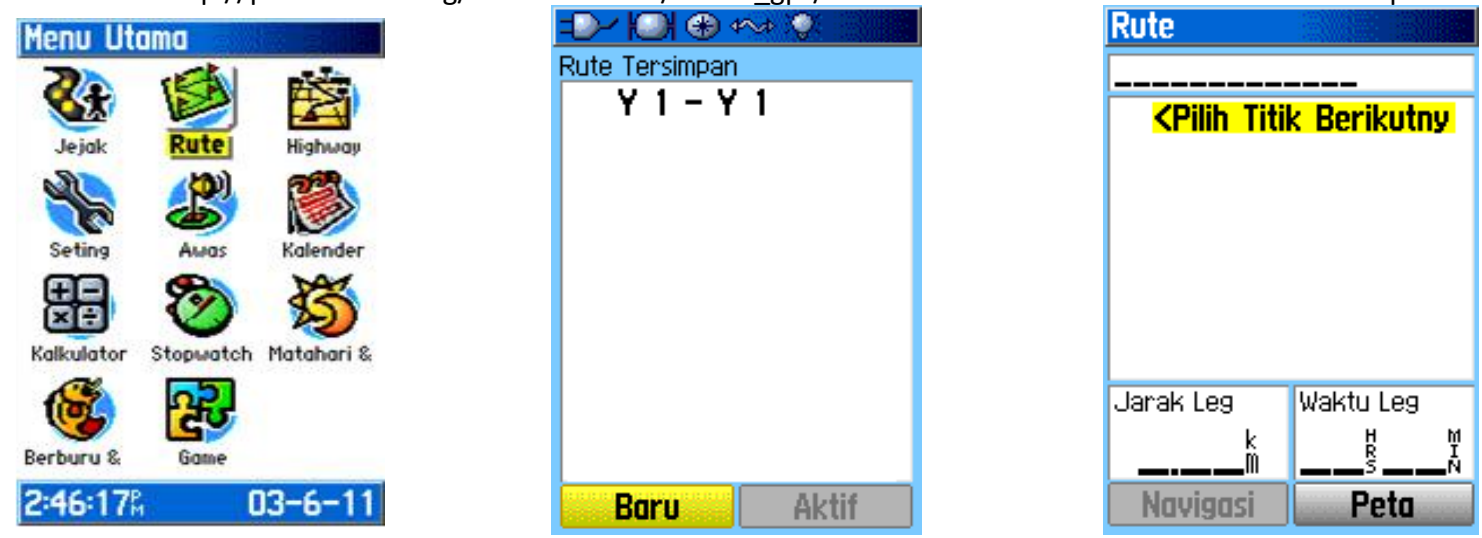

Gambar 15. Proses pengambilan data Route pada GPS

Sumber : http://pusdiklathut.org/baktirimbawan/modul_gps/BAHAN\%20AJAR\%20PENGGUNAAN\%20GPS.pdf 


\section{KESIMPULAN DAN SARAN}

1. KESIMPULAN

- Global Positioning System (GPS) adalah suatu alat yang dapat menentukan suatu posisi relatif di permukaan bumi dengan sistem radio navigasi dan penentu posisi menggunakan satelit

- Penggunaan GPS tidak tergantung pada waktu dan cuaca

- GPS dikelola dalam suatu sistem yang terdiri dari tiga bagian utama yaitu; bagian angkasa, bagian pengontrol, dan bagian pemakai.

- Kegiatan survey yang didukung oleh peralatan yang optimum akan menghasilkan output yang memuaskan.

2. SARAN

- Perlu dilakukan kegiatan pelatihan ilmiah secara teratur supaya para staf pengajar bisa mendapatkan informasi dan pengetahuan yang baru dalam pengembangan ilmunya.

\section{DAFTAR PUSTAKA}

[1]. Firmansyah, Esa. 2016. Pemanfaatan Global Positioning System (GPS) untuk Menghitung Luas Tanah. Sumedang:STMIK.

[2]. Maesaroh,Siti dkk. 2016. Praktikum Survey GPS.Yogyakarta:Universitas Gadjah Mada.

[3]. Purworaharjo,U.U.1985. Ilmu Ukur Tanah.Bandung: Fakultas Teknik Sipil dan Perencanaan ITB.

[4]. Safrel, Ispen. 2010. Peran Informal Geo-Spasial Untuk Menunjang Konsep Kampus Konservasi. Semarang: Universitas Negeri Semarang.

[5]. Sinuraya, Edim. 2010. Pembuatan Peta Wilayah Kecamatan dengan Menggunakan Global Positioning System. Medan: Universitas Negeri Medan.
[6]. Yulfa, Arie. 2007. Pembuatan Peta Situasi Dua Dimensi Menggunakan Alat Ukur Sederhana.Padang: Universitas Negeri Padang.

[7]. Camargus.com.6 GPS Navigasi Termurah dan Terbaik di Indonesia. https://camargus.com/magazine/231 (diakses 17 Desember 2018)

[8]. Mantugaul.wordpress.com. Review GPSMAP Garmin 78s, Generasi Penerus 76csx. https://mantugaul.wordpress.com/2010/07/27/reviewgpsmap-garmin-78s-generasi-penerus-76csx/ (diakses 17 Desember 2018)

[9]. Wptrafficanalyzer.in. Route between two locations with waypoints in Google Map Android API V2. http://wptrafficanalyzer.in/blog/route-between-twolocations-with-waypoints-in-google-map-android-apiv2/ (diakses 17 Desember 2018)

[10]. Chsmith.com.au. Garmin Striker 7sv CHIRP Fishfinder And Track Plotter. https://www.chsmith.com.au/Products/Garmin-Striker7sv-CHIRP-Fishfinder.html (diakses 18 Desember 2018)

[11]. Solusitek.com. Panduan Singkat Aplikasi GPS Tracker. http://www.solusitek.com/?p=3161 (diakses 18 Desember 2018)

[12]. Tracklogs.co.uk. How does a GPS compass work? http://www.tracklogs.co.uk/cgi-

$\mathrm{bin} /$ publ/user.cgi?obj=support\&mod=kbase $\&$ view $=158$ 85925 (diakses 18 Desember 2018)

[13]. Paoir.wordpress.com. My Tracks. https://paoir.wordpress.com/2011/07/07/my-tracks/ (diakses 18 Desember 2018)

[14]. Pctmap.net. Elevation Gain on the Pacific Crest Trail. https://www.pctmap.net/2014/03/elevation-gain-onthe-pacific- crest-trail/ (diakses 18 Desember 2018) 